Article

\title{
Antifungal Efficacy of Marine Macroalgae against Fungal Isolates from Bronchial Asthmatic Cases
}

\author{
Suresh Mickymaray ${ }^{1, *}$ and Wael Alturaiki ${ }^{1,2}$ \\ 1 Department of Biology, Central Bioscience Research Laboratories (CBRL), College of Science, Al-Zulfi-, \\ Majmaah University, Majmaah 11952, Riyadh Region, Saudi Arabia \\ 2 Department of Medical Laboratories, College of Applied Medical Sciences, Majmaah University, \\ Majmaah 11952, Riyadh Region, Saudi Arabia; w.alturaiki@mu.edu.sa \\ * Correspondence: s.maray@mu.edu.sa or drsuresh.maray@gmail.com; Tel.: +96-658-231-5293
}

Received: 10 October 2018; Accepted: 16 November 2018; Published: 20 November 2018

check for updates

\begin{abstract}
Fungal sensitization is very common in bronchial asthmatic cases, and the connection with airway colonization by fungi remains uncertain. Antifungal therapy failure is a significant fraction of the cost and morbidity and mortality in the majority of the asthmatic cases. Hence, the present study aimed to investigate the antifungal activity of five marine macroalgae-Acanthaophora specifera, Cladophoropsis sp., Laurencia paniculata, Tydemania sp., and Ulva prolifera-which were tested on selected fungal pathogens isolated from 15 sputum of 45 bronchial asthmatic patients. The highest antifungal activity was observed in ethanol fractions of L. paniculata followed by $U$. prolifera, Cladophoropsis sp., A. specifera, and Tydemania sp. The minimum fungicidal concentration and minimum inhibitory concentration values of the ethanolic fractions of algal species were found to be $125-1000 \mu \mathrm{g} / \mathrm{mL}$ and $125-500 \mu \mathrm{g} / \mathrm{mL}$, respectively. The algal extracts contained terpene alcohol, diterpene, steroids, sesquiterpene, and sesquiterpene alcohol, as determined by GC-MS/MS analyses. The present study shows that the marine macroalgae containing bioactive compounds had excellent inhibitory activity against a variety of fungal pathogens, which may be useful for combating fungal infections and recovering from chronic asthmatic states.
\end{abstract}

Keywords: bronchial asthma; fungal isolates; macroalgae; ethanolic fractions; fungicidal actions

\section{Introduction}

Bronchial asthma is an inflammatory illness of the airways with characterized hypersensitiveness that could be deteriorated by several factors. It is a serious public health problem, affecting people of all ages with characterized symptoms of chest tightness, dyspnea, cough, and wheeze [1]. A common cause is consistent exposure to allergens, of which fungi play a substantial role. Fungal sensitization is very common in bronchial asthmatic cases, and the connection with airway colonization by fungi remains uncertain. Antifungal therapeutic failures increase the cost of treatment, morbidity, and mortality in over $80 \%$ of asthmatic cases in low and lower middle-income countries [2,3]. Various studies associated with antimicrobial resistance (AMR) predict that the death toll owing to AMR may exceed 10 million by 2050, potentially leading to greater mortality when compared with various malignancies [4-6]. The resistance of pathogenic fungi to existing antibiotics has become a global epidemic. Therapeutic drugs of choices for invasive fungal infections are very minimal when compared to therapeutic choices for bacterial infections [7]. In clinical practice, only three classes of antifungal drugs are available, i.e., polyenes, azoles, and echinocandins. In the last 30 years of therapeutic research, only a few antifungal drugs were elucidated [6]. Traditional plant-based medicine and bioactive natural products are being consumed as therapeutic medicine to enhance the prevailing treatments with fewer side effects [8]. 
Marine macroalgae are macroscopic, multicellular organisms, commonly known as seaweeds and classified as green algae (Chlorophyta), red algae (Rhodophyta), and brown algae (Phaeophyta). The majority of the algal species produce novel secondary metabolites due to extreme climatic and environmental stress such as salinity, light, temperature, and marine chemical diversity. They are a prospective source for structurally unique secondary metabolites with a wide range of biological activities such as antimicrobial [9], antiviral [10], antioxidant [11], anticancer [12], and anti-inflammatory [13] properties. Furthermore, they were reported for various bioactive compounds including alkaloids, polysaccharides, terpenes, phlorotannins, sterols, quinones, carbohydrates, proteins, minerals, lipids, polyunsaturated fatty acids, polyphenols, tocopherols, vitamin $\mathrm{C}$, amino acids, carotenoids, chlorophylls, and phycobilins [14,15]. The Red Sea coast has an extensive coastline with an immense diversity of marine algae. Acanthophora spicifera and Laurencia paniculata are species of marine red algae in the class Florideophyceae under the phylum Rhodophyta. Cladophoropsis sp., Tydemania sp., and Ulva prolifera (synonymous with Enteromorpha prolifera) are species of marine green algae in the class Ulvophyceae under the phylum Chlorophyta. They are abundant in the Red Sea coast of Yanbu, Kingdom of Saudi Arabia throughout the year. According to previous reports in the literature, the antibacterial activity of marine macroalgae was extensively studied [16-19]. However, few reports are available on the antifungal activity of marine macroalgal species. Hence, the present study aimed to investigate the antifungal activity of marine macroalgae collected from the Red Sea coast against fungal pathogens isolated from sputum of moderately severe chronic bronchial asthmatic patients, who seek medical attention at Zulfi General Hospital, Kingdom of Saudi Arabia.

\section{Results}

Immunoglobulin E (IgE) estimation confirmed the sensitization and allergic reactions of chronic asthmatic cases. The levels of IgE detected in the patients ranged from 200-430 IU/mL, with $100 \mathrm{IU} / \mathrm{mL}$ considered as a reference value (Figure 1a). About 18 fungal pathogens were isolated from 15 cases out of 45 samples processed. The isolated fungi were identified as follows: Candida albicans $(n=11$, $61.11 \%)$, Aspergillus niger $(n=4,22.22 \%)$, Mucor species $(n=1,5.55 \%)$, Paecilomyces species $(n=1$, $5.55 \%)$, and unknown filamentous fungi $(n=1,5.55 \%)$. The four major fungal isolates-Candida albicans, Aspergillus niger, Mucor species, and Paeciliomyces species-were taken as representative organisms for the antifungal study against algal extracts (Figure 1b). The filamentous fungi were identified based on colony morphology followed by lactophenol cotton blue mount, as well as a germination tube test (Figure 1c). The results of the antifungal activity of the studied five algal fractions are summarized in Table 1. The ethanolic fractions of L. paniculata and $U$. prolifera showed considerable antifungal activity with inhibition zone diameters varying from 16 to $17.6 \mathrm{~mm}$ at a concentration of $1000 \mu \mathrm{g} / \mathrm{mL}$ against all the tested organisms. Their antifungal activity was comparable to the standard antibiotic (amphotericin B, 100 units) used. The ethanolic fraction of Cladophoropsis sp. performed better in the inhibition of the growth of all kinds of tested fungi with a moderate zone of inhibition (10.6-11.6 mm). A. spicifera showed the lowest antifungal activity (10-10.6 mm) except for Mucor sp.; however, the ethanolic fractions of Tydemania sp. did not show any noticeable activity against the tested fungal pathogens except for Mucor sp. The ethanolic fractions of algal species were found to be the most active fractions with the exception of Tydemania sp., whereas petroleum ether fractions were not active on the tested pathogens.

The activity of the ethanolic fractions of five marine macroalgae-A. spicifera, Cladophoropsis sp., L. paniculata, Tydemania sp., and U. prolifera-against asthmatic fungal isolate was assessed using the agar well-diffusion method. The results were also compared with the growth inhibition of asthmatic fungal isolates by the standard antifungal drug (amphotericin B, 100 units) as indicated. Experiments were conducted in triplicate and results were expressed as means \pm standard deviation. The superscript letters $(\mathrm{a}$ and $\mathrm{b}$ ) above denote significant differences at $p<0.05$ using Tukey's test. 
(a) Sensitization and allergic reaction of Asthmatic cases

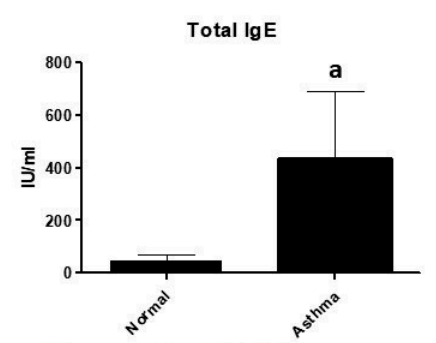

Reference value: $<100 \mathrm{IU} / \mathrm{mL}$ (b) Isolated fungal species from asthmatic cases

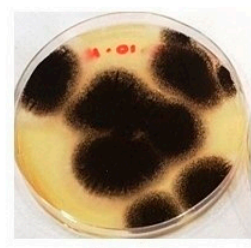

A. niger

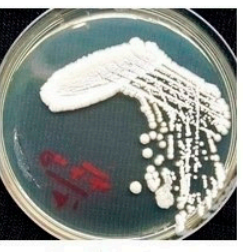

C. albicans

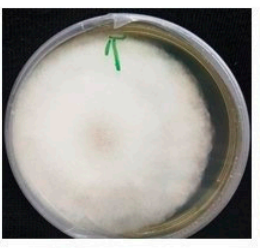

Mucorsp.

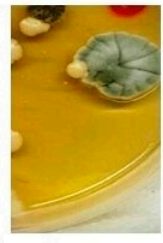

Paecilomyces sp. (c) Microscopical characterization of fungus
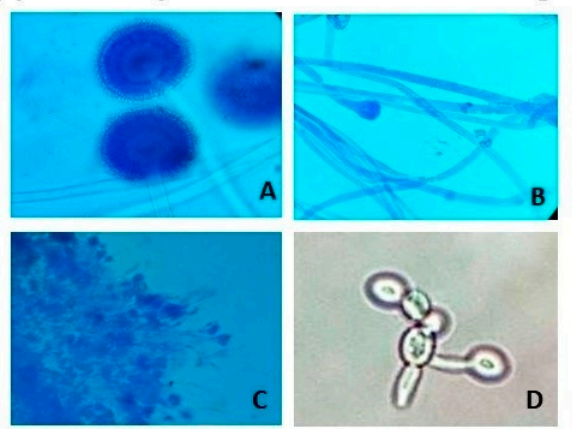

Figure 1. (a) Total immunoglobulin E (IgE), sensitization, and allergic reactions of asthmatic cases; (b) isolated fungal species from asthmatic cases; (c) microscopical characterization of fungus with lactophenol cotton blue mount: A, Aspergillus niger; B, aseptate hyphae and young conidiophores of Mucor sp; C, Paecilomyces sp.; D, germination tube test positivity of Candida albicans. Results are means $\pm \mathrm{SD}$. The letter a above the average bar denotes a significant difference with the normal at $p<0.05$ using Tukey's test.

Table 1. Antifungal activity of ethanolic factions of marine macroalgae.

\begin{tabular}{|c|c|c|c|c|c|c|}
\hline \multirow{2}{*}{ Fungal Isolates } & \multicolumn{5}{|c|}{$\begin{array}{l}\text { Ethanol Fractions: Zone of Inhibition }(\mathrm{mm}) \text { with Standard Deviation for } \\
\text { Triplicates }(1000 \mu \mathrm{g} / \mathrm{mL})\end{array}$} & \multirow{2}{*}{$\begin{array}{c}\begin{array}{c}\text { Standard } \\
\text { Antibiotic }\end{array} \\
\text { (Amphotericin } \\
\text { B; } 100 \text { units) }\end{array}$} \\
\hline & $\begin{array}{l}\text { Acanthophora } \\
\text { spicifera }\end{array}$ & $\begin{array}{l}\text { Cladophoropsis } \\
\text { sp. }\end{array}$ & $\begin{array}{l}\text { Laurencia } \\
\text { paniculat }\end{array}$ & $\begin{array}{l}\text { Tydemania } \\
\text { sp. }\end{array}$ & $\begin{array}{c}\text { Ulva } \\
\text { prolifera }\end{array}$ & \\
\hline Aspergillus niger & $10.6 \pm 1.15^{\mathrm{a}}$ & $11.6 \pm 0.57^{\mathrm{a}, \mathrm{b}}$ & $16.3 \pm 0.57$ & - & $16 \pm 2$ & $16.33 \pm 0.57$ \\
\hline Candida albicans & $10 \pm 2^{\mathrm{a}}$ & $11 \pm 2^{a, b}$ & $17.6 \pm 0.57$ & - & $17.3 \pm 1.15$ & $17 \pm 1$ \\
\hline Mucor sp. & - & $10.6 \pm 1.15^{\mathrm{a}}$ & $17 \pm 1$ & $10 \pm 1^{\mathrm{a}}$ & $17 \pm 1$ & $17.33 \pm 0.57$ \\
\hline Paecilomyces sp. & $10.6 \pm 1.15^{\mathrm{a}}$ & $11.3 \pm 1.15^{\mathrm{a}}$ & $17.3 \pm 1.15^{b}$ & - & $16.6 \pm 1.15$ & $16.66 \pm 0.57$ \\
\hline
\end{tabular}

Considering the superior antifungal potential of the ethanolic fractions of L. paniculata and U. prolifera, they were preferred for minimum inhibitory concentration (MIC) and minimum fungicidal concentration (MFC) analysis. The MIC and MFC values with fungicidal ratios of ethanolic fractions of algal species are shown in Table 2. Both MIC and MFC analyses on ethanolic fractions of L. paniculata and U. prolifera revealed the lowest value of $125 \mu \mathrm{g} / \mathrm{mL}$ with a fungicidal ratio of 1:1 in C. albicans. The fungicidal effect of ethanolic fractions of L. paniculata and $U$. prolifera was due to their MFC/MIC ratio, which was between 1:1 and 1:2. The spectral analysis of ethanolic fractions of L. paniculata and $U$. prolifera are shown in Figures 2 and 3 . In total, 33 and 23 prominent peaks were obtained in the ethanolic fractions of L. paniculata and $U$. prolifera, respectively. Among them, the 12 and 10 identified antimicrobial compounds, respectively are given in Tables 3 and 4 . There were three common antimicrobial compounds, i.e., 3,7,11,15-tetramethyl-2-hexadecene-1-ol, phytol, and dasycarpidan-1-methanol acetate (ester), identified in both fractions. The 3,7,11,15-tetramethyl-2-hexadecene-1-ol (7.32\%) and cholestan-3-ol 2-methylene- $(3 \beta, 5 \alpha)(13.91 \%)$ compounds are the major antimicrobial contents present in the ethanolic fractions of L. paniculata and $U$. prolifera, respectively. The biological activities listed in the tables are 
based on Dr. Duke's Phytochemical and Ethnobotanical Databases created by Dr. Jim Duke of the Agricultural Research Service, United States Department of Agriculture (USDA).

Table 2. Minimum inhibitory concentration (MIC) and minimum fungicidal concentration (MFC) of ethanolic fractions of L. paniculata and U. prolifera with fungicidal ratio.

\begin{tabular}{cccccccc}
\hline \multirow{2}{*}{ S.No } & \multirow{2}{*}{$\begin{array}{c}\text { Fungal } \\
\text { Pathogens }\end{array}$} & $\begin{array}{c}\text { MIC } \\
\boldsymbol{\mu g} / \mathbf{m L}^{*}\end{array}$ & $\begin{array}{c}\text { MFC } \\
\boldsymbol{\mu g} / \mathbf{m L}^{* *}\end{array}$ & $\begin{array}{c}\text { Fungicidal } \\
\text { Ratio }\end{array}$ & $\begin{array}{c}\text { MIC } \\
\mu \mathrm{g} / \mathbf{m L}^{*}\end{array}$ & $\begin{array}{c}\text { MFC } \\
\boldsymbol{\mu g} / \mathbf{m L}^{* *}\end{array}$ & $\begin{array}{c}\text { Fungicidal } \\
\text { Ratio }\end{array}$ \\
\hline 1. & A.niger & 250 & 500 & $1: 2$ & 500 & 1000 & $1: 2$ \\
2. & C. albicans & 125 & 125 & $1: 1$ & 125 & 125 & $1: 1$ \\
3. & Mucor sp. & 250 & 500 & $1: 1$ & 500 & 1000 & $1: 2$ \\
4 & Paecilomyces sp. & 250 & 500 & $1: 2$ & 500 & 500 & $1: 1$ \\
\hline
\end{tabular}

* The Roswell Park Memorial Institute (RPMI) broth microdilution technique was applied to determine the MIC of the ethanolic fraction of L. paniculata and U. prolifera against the asthmatic fungal isolates. The MIC was defined as the lowest concentration that exhibited a 100\% visual reduction in turbidity when compared with the control well at $48 \mathrm{~h}$. ${ }^{* *}$ The lowest algal extract concentration at which no fungal growth was identified even after four days of incubation.

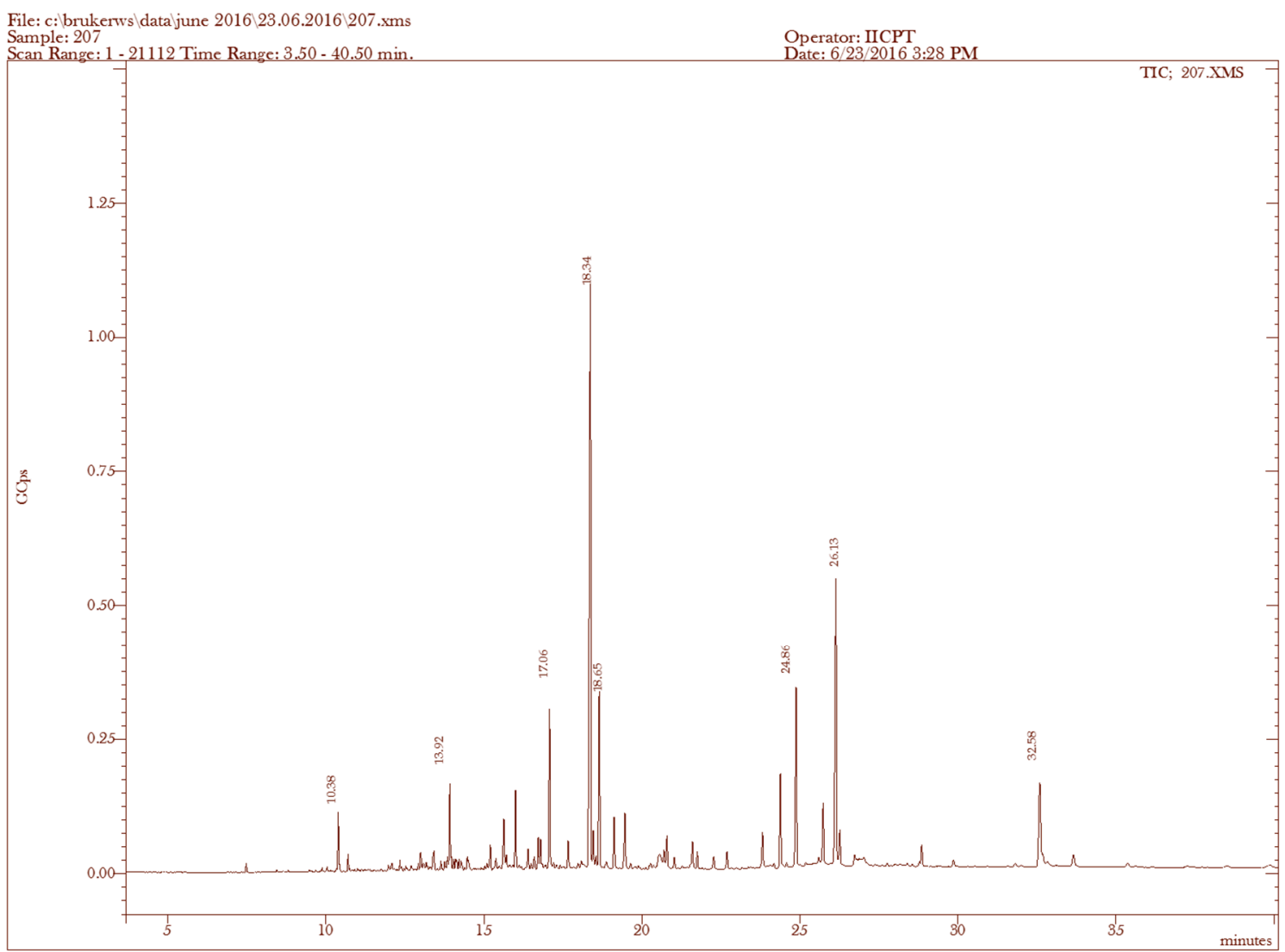

Figure 2. GC-MS/MS chromatogram formed by ethanolic fractions of Laurencia paniculata. The 436-GC Bruker model coupled with a triple quadrupole mass spectrometer was used to study the chemical composition of the ethanolic fractions of the two plants. The MS Workstation 8 and the library database of National Institute Standard and Technology (NIST Version 11.0) were used for the identification of the chemical components. 
Table 3. Bioactive compounds identified in ethanolic fractions of L. paniculata by GC-MS/MS analysis.

\begin{tabular}{|c|c|c|c|c|c|c|c|}
\hline Sample & RT (min) & Name of the Compound & $\begin{array}{l}\text { Molecular } \\
\text { Formula }\end{array}$ & MW (g/mol) & Peak Area \% & $\begin{array}{l}\text { Compound } \\
\text { Nature }\end{array}$ & ** Activity \\
\hline 1. & 7.47 & (-)-Aristolene & $\mathrm{C}_{15} \mathrm{H}_{24}$ & 204 & 0.32 & Sesquiterpene & $\begin{array}{l}\text { Antibacterial, anti-inflammatory, } \\
\text { fungicidal }\end{array}$ \\
\hline 2. & 9.88 & 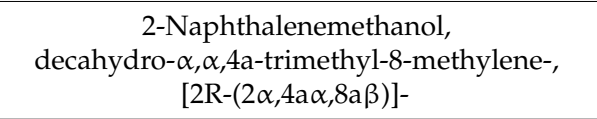 & $\mathrm{C}_{15} \mathrm{H}_{26} \mathrm{O}$ & 222 & 0.18 & $\begin{array}{l}\text { Sesquiterpene } \\
\text { alcohol }\end{array}$ & $\begin{array}{l}\text { Antibacterial, anti-inflammatory, } \\
\text { fungicidal }\end{array}$ \\
\hline 3. & 10.38 & $\begin{array}{c}\text { 1-Naphthalenemethanol, } \\
1,4,4 \mathrm{a}, 5,6,7,8,8 \mathrm{a} \text {-octahydro-2,5,5,8a-tetramethyl- }\end{array}$ & $\mathrm{C}_{15} \mathrm{H}_{26} \mathrm{O}$ & 222 & 1.73 & $\begin{array}{l}\text { Sesquiterpene } \\
\text { alcohol }\end{array}$ & $\begin{array}{l}\text { Antibacterial, anti-inflammatory, } \\
\text { fungicidal }\end{array}$ \\
\hline 4. & 10.71 & 1,6,10-Dodecatrien-3-ol, 3,7,11-trimethyl-, (E)- & $\mathrm{C}_{15} \mathrm{H}_{26} \mathrm{O}$ & 222 & 0.67 & $\begin{array}{l}\text { Sesquiterpene } \\
\text { alcohol }\end{array}$ & $\begin{array}{l}\text { Antibacterial, anti-inflammatory, } \\
\text { fungicidal }\end{array}$ \\
\hline 5. & 13.92 & 3,7,11,15-Tetramethyl-2-hexadecen-1-ol & $\mathrm{C}_{20} \mathrm{H}_{40} \mathrm{O}$ & 296 & 7.32 & Terpene alcohol & Antimicrobial, anti-inflammatory \\
\hline 6. & 17.66 & Phytol & $\mathrm{C}_{20} \mathrm{H}_{40} \mathrm{O}$ & 296 & 2.03 & Diterpene & $\begin{array}{l}\text { Antimicrobial, anti-inflammatory } \\
\text { Anticancer, }\end{array}$ \\
\hline 7. & 18.65 & $\begin{array}{c}\text { Androst-5-en-17-one, } \\
\text { 3-(acetyloxy)-19-hydroxy-, (3ß)- }\end{array}$ & $\mathrm{C}_{21} \mathrm{H}_{30} \mathrm{O}_{4}$ & 346 & 5.98 & Steroid & $\begin{array}{l}\text { antimicrobial, anti-inflammatory } \\
\text { Anticancer, antiasthma }\end{array}$ \\
\hline 8. & 21.74 & trans-Z- $\alpha$-Bisabolene epoxide & $\mathrm{C}_{15} \mathrm{H}_{24} \mathrm{O}$ & 220 & 1.35 & $\begin{array}{c}\text { Sesquiterpene } \\
\text { alcohol }\end{array}$ & $\begin{array}{l}\text { Anti-tumor, antibacterial, } \\
\text { anti-inflammatory, fungicidal. }\end{array}$ \\
\hline 9. & 22.69 & Dasycarpidan-1-methanol, acetate (ester) & $\mathrm{C}_{20} \mathrm{H}_{26} \mathrm{~N}_{2} \mathrm{O}_{2}$ & 326 & 0.76 & $\begin{array}{l}\text { Nitrogen } \\
\text { compound }\end{array}$ & Antimicrobial \\
\hline 10. & 28.85 & Cholesta-3,5-diene & $\mathrm{C}_{27} \mathrm{H}_{44}$ & 368 & 0.50 & Steroid & $\begin{array}{l}\text { Antimicrobial, anti-inflammatory, } \\
\text { anticancer, antiasthma }\end{array}$ \\
\hline 11. & 32.58 & Cholesterol & $\mathrm{C}_{27} \mathrm{H}_{46} \mathrm{O}$ & 386 & 2.06 & Steroid & $\begin{array}{l}\text { Antimicrobial, anti-inflammatory, } \\
\text { anticancer, antiasthma }\end{array}$ \\
\hline 12. & 35.36 & Cholest-4-en-3-one & $\mathrm{C}_{27} \mathrm{H}_{44} \mathrm{O}$ & 384 & 0.05 & Steroid & $\begin{array}{l}\text { Antimicrobial, anti-inflammatory, } \\
\text { anticancer, antiasthma }\end{array}$ \\
\hline
\end{tabular}

** The activity of the identified phytoconstituents was based on Dr. Duke's Phytochemical and Ethnobotanical Databases. RT: retention time of the identified compounds; MW: molecular weight of the identified compounds. 
Table 4. Bioactive compounds identified in ethanolic fractions of $U$. prolifera by GC-MS/MS analysis.

\begin{tabular}{|c|c|c|c|c|c|c|c|}
\hline Sample & RT (min) & Name of the Compound & $\begin{array}{c}\text { Molecular } \\
\text { Formulae }\end{array}$ & MW (g/mol) & Peak Area \% & $\begin{array}{l}\text { Compound } \\
\text { Nature }\end{array}$ & ** Activity \\
\hline 1. & 12.10 & n-Heptadecanol-1 & $\mathrm{C}_{17} \mathrm{H}_{36} \mathrm{O}$ & 256 & 0.75 & $\begin{array}{l}\text { Alcoholic } \\
\text { compound }\end{array}$ & Antimicrobial \\
\hline 2. & 13.97 & 3,7,11,15-Tetramethyl-2-hexadecen-1-ol & $\mathrm{C}_{20} \mathrm{H}_{40} \mathrm{O}$ & 296 & 3.38 & Terpene alcohol & $\begin{array}{l}\text { Antimicrobial, } \\
\text { anti-inflammatory }\end{array}$ \\
\hline 3. & 17.65 & Phytol & $\mathrm{C}_{20} \mathrm{H}_{40} \mathrm{O}$ & 296 & 5.28 & Diterpene & $\begin{array}{c}\text { Antimicrobial, anti-inflammatory, } \\
\text { anticancer, diuretic }\end{array}$ \\
\hline 4. & 22.65 & Dasycarpidan-1-methanol acetate (ester) & $\mathrm{C}_{20} \mathrm{H}_{26} \mathrm{~N}_{2} \mathrm{O}_{2}$ & 326 & 1.54 & $\begin{array}{l}\text { Nitrogen } \\
\text { compound }\end{array}$ & Antimicrobial \\
\hline 5. & 30.97 & Cholestan-3-ol, 2-methylene-, $(3 \beta, 5 \alpha)$ - & $\mathrm{C}_{28} \mathrm{H}_{48} \mathrm{O}$ & 400 & 13.91 & Steroid & $\begin{array}{l}\text { Antimicrobial, anti-inflammatory, } \\
\text { anticancer, antiasthma }\end{array}$ \\
\hline 6. & 31.63 & Stigmasta-5,22-dien-3-ol, acetate, (3ß)- & $\mathrm{C}_{31} \mathrm{H}_{50} \mathrm{O}_{2}$ & 454 & 4.85 & Steroid & $\begin{array}{l}\text { Antimicrobial, anti-inflammatory, } \\
\text { anticancer, antiasthma }\end{array}$ \\
\hline 7. & 31.98 & $\begin{array}{c}\text { Pregn-5-en-20-one, 3-(acetyloxy)-17-hydroxy-, } \\
\text { (3ß)- }\end{array}$ & $\mathrm{C}_{23} \mathrm{H}_{34} \mathrm{O}_{4}$ & 374 & 5.24 & Steroid & $\begin{array}{l}\text { Antimicrobial, anti-inflammatory, } \\
\text { anticancer, antiasthma }\end{array}$ \\
\hline 8. & 32.30 & Allopregn-5,16-diene-3 $\beta$-ol-20-one acetate & $\mathrm{C}_{23} \mathrm{H}_{32} \mathrm{O}_{3}$ & 356 & 9.93 & Steroid & $\begin{array}{l}\text { Antimicrobial, anti-inflammatory, } \\
\text { anticancer, antiasthma }\end{array}$ \\
\hline 9. & 32.76 & 5,16,20-Pregnatriene-3beta,20-diol diacetate & $\mathrm{C}_{25} \mathrm{H}_{34} \mathrm{O}_{4}$ & 398 & 6.04 & Steroid & $\begin{array}{l}\text { Antimicrobial, anti-inflammatory, } \\
\text { anticancer, antiasthma }\end{array}$ \\
\hline 10. & 37.73 & Stigmasta-5,24(28)-dien-3-ol, (3ß,24Z)- & $\mathrm{C}_{29} \mathrm{H}_{48} \mathrm{O}$ & 412 & 8.33 & Steroid & $\begin{array}{l}\text { Antimicrobial, anti-inflammatory, } \\
\text { anticancer, antiasthma }\end{array}$ \\
\hline
\end{tabular}

** The activity of the identified phytoconstituents was based on Dr. Duke's Phytochemical and Ethnobotanical Databases. RT: retention time of the identified compounds; MW: molecular weight of the identified compounds. The chemical composition of the ethanolic fraction of L. paniculata and U. prolifera was determined using gas chromatography (436-GC Bruker model) coupled with a triple quadrupole mass spectrometer 


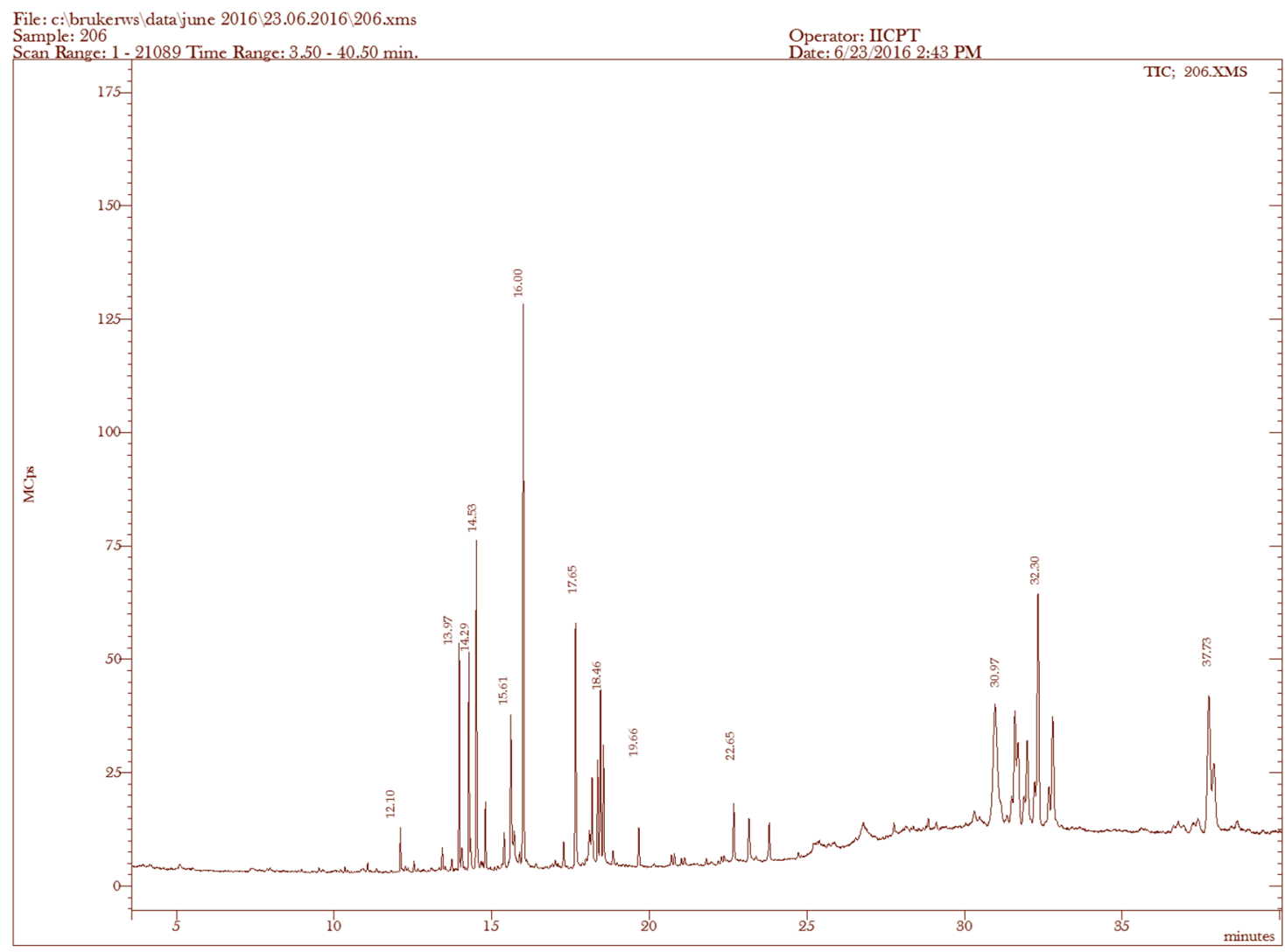

Figure 3. GC-MS/MS chromatogram formed by ethanolic fractions of Ulva prolifera. The 436-GC Bruker model coupled with a triple quadrupole mass spectrometer was used to study the chemical composition of the ethanolic fractions of the two plants. The MS Workstation 8 and the library database of National Institute Standard and Technology (NIST Version 11.0) were used for the identification of the chemical components.

\section{Discussion}

In the present study, ethanol and petroleum ether were used for the extraction of antifungal compounds from five selected macroalgal species. The ethanolic fractions of algal species exhibited superior antifungal activity, and petroleum ether fractions did not show any activity against the tested pathogens. Results obtained in the present study indicated that hydrophilic solvent fractions provided better activity. These results are in harmony with earlier reports [20-25]. In the present study, the species of Rhodomelaceae (L. paniculata) showed the strongest antifungal activity against the tested pathogens, which is in agreement with the findings of Rahelivao et al. [26]. They reported that the methanol extract of L. complanata exhibited antifungal activity against $C$. albicans with an inhibition zone of $11.5 \mathrm{~mm}$. Previously, Alarif and his coworkers [27] isolated cholestane derivative $3 \alpha, 6 \alpha$-dihydroxy-5beta-cholestan-12-one and aldehyde derivative (E)-2-\{(E) tridec-2-en-2-yl\} heptadec-2-enal from L. papillosa collected from the Red Sea in Saudi Arabia, which showed considerable antifungal activity against $C$. albicans, A. fumigatus, and A. flavus.

In this study, an ethanolic fraction of $U$. prolifera exhibited inhibition zones (zone range: 16-17.3 $\mathrm{mm}$ ) on tested fungi. The results agree with the findings of Chowdhury et al. [28], who reported that the growth of C. albicans was inhibited $(15 \mathrm{~mm})$ by an ethanolic extract of Enteromorpha prolifera. Correspondingly, the antifungal activity of $U$. lactuca and $U$. fasciata studied by Shobier et al. [29] against Aspergillus flavipes and C. albicans and found activities ranging from 10 to $32 \mathrm{~mm}$. Additionally, Mashjoor et al. [30] demonstrated the antifungal activity in methanol and ethyl acetate extracts of $U$. flexuosa against $C$. albicans, and detected a moderate zone of inhibition (13 and $17 \mathrm{~mm}$ ). Previously Ertürk and Taş [31] reported that Ulva rigida extracts showed activity against $A$. niger and C. albicans 
with $12 \mathrm{~mm}$ of inhibition zone. On the contrary, organic solvents fractions obtained from U. lactuca showed no activity against $C$. albicans reported by Guedes et al. [32]. In addition, $A$. spicifera had the lowest antifungal activity, in discrepancy with Pandian et al. [33] and Chowdhury et al. [28]. They reported that $A$. spicifera exhibited moderate antifungal activity against $A$. niger, Microsporum gypseum, and C. albicans.

Based on the broth dilution technique, the lowest concentration of ethanolic factions of L. paniculata and $U$. prolifera showed an MFC and MIC at $125 \mu \mathrm{g} / \mathrm{mL}$ against $C$. albicans. These results are in accordance with the findings of Shobier et al. [29], who reported that $U$. fasciata extract demonstrated an MFC and MIC at 155 and $128 \mu \mathrm{g} / \mathrm{mL}$ against A. flavipes and C. albicans. Similar work was done by Ertürk and Taş [31], who demonstrated that the antifungal activity of $U$. rigida extracts against $A$. niger and C. albicans had an MFC and MIC of more than $25 \mu \mathrm{g} / \mathrm{mL}$ and $10 \mu \mathrm{g} / \mathrm{mL}$, respectively. Furthermore, a study by Genovese et al. [34] reported that the red algae Asparagopsis taxiformis showed antifungal activity against $A$. fumigatus, $A$. terreus, and $A$. flavus with a minimum inhibitory concentration range between $0.15 \mathrm{mg} / \mathrm{mL}$ and $5 \mathrm{mg} / \mathrm{mL}$. From the results of the present study, it is clear that ethanol was the most effective solvent for the extraction of the bioactive compounds compared to petroleum ether. Furthermore, L. paniculata was the most effective marine algae against the five tested fungal species, followed by U. prolifera, Cladophoropsis sp., A. specifera, and Tydemania sp. Collectively, antifungal activity depends on the algal species, the efficiency of the extraction method, and the resistance characteristic of the tested fungi. The GC-MS/MS analysis showed various antimicrobial compounds present in ethanolic fractions of L. paniculata and U. prolifera. The two fractions contained a wide range of chemical classes, namely sesquiterpene, terpene, diterpene, steroid, etc. These compounds were already reported to have certain biological activities [29]. The genus Laurencia is a fruitful source of chemical diversity, including mainly sesquiterpenoids, diterpenoids, and terpenoids [35]. The identified sesquiterpenes were reported from various species of Laurencia, such as L. tristicha [36], L. mariannensis [37], L. similis [38], L. saitoi [39], and L. okamurai [40,41]. In this study, the ethanolic

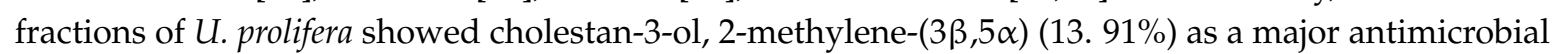
compound. Previous chemical investigation on $U$. lactuca methanolic extract revealed 42 compounds, of which the major components were 1,2-benzene dicarboxylic acid, bis(2-ethylhexyl) ester and palmitic acid, reported by Abbassy et al. [42]. Another study by Shobier et al. [29] found that the methanolic extracts of $U$. fasciata contained 17 compounds, and the prevailing compounds were palmitic acid, methylester, trichloromethyloxirane, and linolenic acid. The antifungal activity of L. paniculata and $U$. prolifera might be attributed to a wide range of chemical classes identified in the ethanolic fractions.

\section{Materials and Methods}

\subsection{Collection of Macroalgae}

Five macroalgae samples of $A$. spicifera, Cladophoropsis sp., L. paniculata, Tydemania sp., and $U$. prolifera were collected from the rocky shore of the Red Sea coast of Yanbu $\left(24^{\circ} 24^{\prime} 39.5^{\prime \prime} \mathrm{N} ; 3^{\circ} 26^{\prime} 49.2^{\prime \prime}\right.$ E and $24^{\circ} 03^{\prime} 52.25^{\prime \prime} \mathrm{N} ; 38^{\circ} 05^{\prime} 05.1^{\prime \prime} \mathrm{E}$ ), Saudi Arabia (Figure 4). Algal samples were preserved in sterile plastic bags and shipped to the laboratory under cold conditions at $4-8{ }^{\circ} \mathrm{C}$.

\subsection{Extraction of Bioactive Compounds from Algae Using Organic Solvents}

About $5 \mathrm{~kg}$ of five different algal species, namely A. spicifera, Cladophoropsis sp., L. paniculata, Tydemania sp., and $U$. prolifera were harvested from the Red Sea coastal sampling site. The algal samples were separately rinsed with tap water and shade-dried, cut into small pieces, and powdered in a mixer grinder (MX1100XTX Hi-Power Electronic Keypad Blender with Timer, Toronto, OH, USA). Then, $500 \mathrm{~g}$ of a powdered sample of each algal species was extracted separately with $2 \mathrm{~L}$ of selected solvents, ethanol and petroleum ether. The algal powder was filled in the thimble and extracted to exhaustion with the solvents using a Soxhlet extractor (Thermo Fisher Scientific, Waltham, MA, USA) for $24 \mathrm{~h}$. The obtained extracts were concentrated using a rotary flash evaporator (IKA RV 10, IKA 
-Werke GmbH \& Co. KG, Darmstadt, Germany) at room temperature not exceeding $40{ }^{\circ} \mathrm{C}$ to get 45 $\mathrm{g}$ (A. spicifera), $37 \mathrm{~g}$ (Cladophoropsis sp.), $15 \mathrm{~g}$ (L. paniculata), $12 \mathrm{~g}$ (Tydemania sp.), and $8 \mathrm{~g}$ (U. prolifera) of the species. The fractions of algal samples were well preserved in airtight containers and kept at $-20{ }^{\circ} \mathrm{C}$ for further analysis.

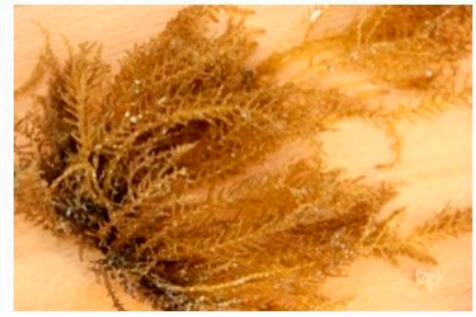

Acanthophora spicifera (Family - Rhodomelaceae)

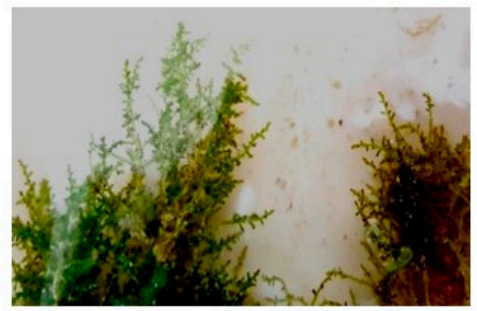

Laurencia paniculata

(Family - Rhodomelaceae)

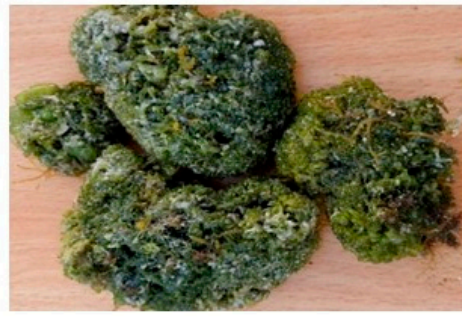

Cladophoropsis sp.

(Family - Siphonocladaceae)

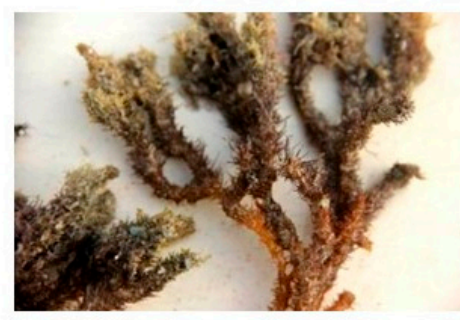

Tydemania sp.

(Family - Udoteaceae)

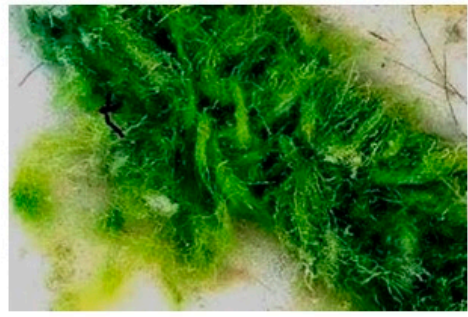

Ulva prolifera

(Family - Ulvaceae)

Figure 4. Aerial view of marine macroalgae collected from the rocky shore of Red sea coasts of Yanbu, Saudi Arabia.

\subsection{Collection of Fungal Pathogens}

\subsubsection{Patients}

In total, 45 sputum samples were obtained from chronic asthmatic (21 male and 24 female) patients with acute respiratory distress, featuring symptoms such as shortness of breath, cough, wheezing, chest tightness, and a few cases of excess mucus secretion. In addition, immunoglobulin E (IgE) was estimated as per the protocol of a human enzyme-linked immunosorbent assay (ELISA) kit (abcum, London, UK), and confirmed the allergic status of asthmatic cases. At the time of sampling, between May 2016 and April 2017, the specialty physicians at Al Zulfi General Hospital, Kingdom of Saudi Arabia, categorized all the patients as moderately severe asthmatics based on their clinical status. Written informed consent was obtained from all patients according to the protocols approved by the Majmaah University Ethical Committee (ID: MUREC-May.24/COM-2017/19). The minimum age of participants was 19 across both genders, and the maximum ages were 97 and 53 for female and male patients, respectively (average age: 39.62). All patients were on medication while the sputum specimen was collected; this medication included short-acting beta-agonists (SABAs) and a few cases with inhaled corticosteroids (ICS).

\subsubsection{Sputum Processing and Identification of Fungal Isolates}

The expectorated samples were stored in ice, and the isolated mucus plug was inoculated within $2 \mathrm{~h}$ into two slants of Sabouraud dextrose agar containing $50 \mu \mathrm{g} / \mathrm{mL}$ chloramphenicol media using a class II biosafety cabinet. One was incubated at $37^{\circ} \mathrm{C}$ and the other was incubated at $25{ }^{\circ} \mathrm{C}$ on the biological oxygen demand incubator for up to three weeks. Gram staining and germination tube test methods identified the grown tissue fungi (C. albicans). The filamentous fungi were determined using colony morphology, as well as lactophenol cotton blue mount. 


\subsubsection{Determination of Antifungal Activity-Agar Well-Diffusion Method}

The antifungal activity of the ethanol and petroleum ether fractions of macroalgal samples were evaluated using the agar well-diffusion method [43]. The inoculum used was prepared using the fungal pathogens from a 24-h culture on Sabouraud dextrose agar; a suspension was made in a sterile saline solution $(0.85 \%)$. The turbidity of the suspension was adjusted with a spectrophotometer at 530 $\mathrm{nm}$ to obtain a final concentration to match that of a $0.5 \mathrm{McFarland}$ standard $\left(1-5 \times 10^{6}\right.$ cells $\left./ \mathrm{mL}\right)[44]$. The culture plates were prepared by pouring $20 \mathrm{~mL}$ of Sabouraud dextrose agar medium. The test fungal cultures were evenly spread over the media using a sterile cotton swab. Then, wells $(6 \mathrm{~mm})$ were made in the medium using a sterile cork borer, and $100 \mu \mathrm{L}$ of the ethanol and petroleum ether fractions of macroalgal samples were transferred into separate wells. Then, these plates were incubated at $27 \pm 2{ }^{\circ} \mathrm{C}$ for $48-72 \mathrm{~h}$. After the incubation period, the results were observed, and the diameter of the inhibition zone around each well was measured. The formation of a clear inhibition zone around the well indicated the presence of antifungal activity. A standard antibiotic disc (amphotericin B, 100 units) was used as a control. All tests were performed in triplicate.

\subsection{Minimum Inhibitory Concentrations (MICs)_Broth Dilution Method}

Inoculum Preparation

The inoculum was prepared according to the method described in the Clinical and Laboratory Standards Institute CLSI M38-A protocol [45]. The inoculum of filamentous fungi is explained briefly. It was prepared by overlaying mature slants with sterile distilled water and gently scraping the surface with a wooden applicator stick. The suspension was permitted to sit for 5 min to allow large particles to settle down and then adjusted spectrophotometrically to the correct optical density for each species as outlined in M38-A, providing an inoculum concentration of $0.4-5 \times 10^{4}$ conidia/mL, which was verified by colony count. The inoculum suspensions were diluted (1:50) in Roswell Park Memorial Institute (RPMI)-1640 medium buffered with $0.165 \mathrm{M}$ morpholine propanesulfonic acid (34.54 g/L) at $\mathrm{pH} 7.0$.

\subsection{Determination of Minimal Fungicidal Concentration (MFC)}

The MFC of each extract was determined by streaking $10 \mu \mathrm{L}$ from the optically clear MIC well to the last growth well, and from the control onto Sabourad Dextrose agar [46]. The plates were incubated at $37^{\circ} \mathrm{C}$ for four days. The MFC was determined as the lowest drug concentration at which no fungal colonies grew even after four days of incubation.

\subsection{Antifungal Agents}

Ethanolic fractions of two algal extracts of L. paniculata and $U$. prolifera were selected as antifungal agents after being condensed and dried using a Soxhlet apparatus method. To prepare, each was dissolved in sterile distilled water following the protocol of CLSI, and stock solutions of $5000 \mu \mathrm{g} / \mathrm{mL}$ were prepared, which were subsequently diluted in RPMI 1640 test medium for further various dilutions.

\subsection{Preparation of Microdilution Plates and Antifungal Assay}

Sterile disposable 96-well flat-bottom microdilution plastic plates with a normal capacity of approximately $300 \mu \mathrm{L}$ were used; $100 \mu \mathrm{L}$ from each of the tubes containing the corresponding concentration $(2 \times$ final concentration) of target algal extracts were dispensed into the wells in each column (from 1 to 10). For example, to column 1, the medium containing $2000 \mu \mathrm{g} / \mathrm{mL}$ was dispensed; to column 2, the medium containing $1000 \mu \mathrm{g} / \mathrm{mL}$ was dispensed. This pattern was continued to column 10, where the medium containing $4 \mu \mathrm{g} / \mathrm{mL}$ was dispensed. To each well of columns 11 and 12, $100 \mu \mathrm{L}$ of RPMI-1640 medium was dispensed. Thus, each well in columns 1-10 contained $100 \mu \mathrm{L}$ 
of twice the final algal extract concentrations (4 to $2000 \mu \mathrm{g} / \mathrm{mL}$ ) in RPMI medium. Columns 11 and 12 contained double-strength RPMI-1640 medium, where one was used as a sterility control (100 $\mu \mathrm{L}$ of medium) and the other considerations were growth controls (100 $\mu \mathrm{L}$ of medium plus $100 \mu \mathrm{L}$ of inoculum) [47]. The final well concentrations reached were 2 to $1000 \mu \mathrm{g} / \mathrm{mL}$ after addition of $100 \mu \mathrm{L}$ of fungal inoculum to each well (columns 1 to 10). After the addition of inoculum, the microdilution plates were incubated at $35^{\circ} \mathrm{C}$ for up to $48 \mathrm{~h}$ or until growth was visible in the sterility control well. Endpoint determination values were read visually with the aid of an inverted reading mirror. The MIC was defined as the lowest concentration that exhibited a $100 \%$ visual reduction in turbidity when compared with the control well at $48 \mathrm{~h}$.

\subsection{GC-MS/MS Analysis}

The chemical composition of algal samples was investigated using GC-MS/MS in electron ionization mode. The GC-MS/MS was a Scion 436-GC Bruker model coupled with a triple quadrupole mass spectrometer with a fused silica capillary column BR-5MS (5\% diphenyl/95\% dimethylpolysiloxane) of length $30 \mathrm{~m}$, internal diameter $0.25 \mathrm{~mm}$, and thickness $0.25 \mu \mathrm{m}$. Helium gas (99.999\%) was used as the carrier gas at a constant flow rate of $1 \mathrm{~mL} / \mathrm{min}$ and an injection volume of $2 \mu \mathrm{L}$ was employed (split ratio of 10:1). The column oven temperature program was as follows: $110^{\circ} \mathrm{C}$ held for $3 \mathrm{~min}$, up to $200{ }^{\circ} \mathrm{C}$ at $20^{\circ} \mathrm{C} / \mathrm{min}$ (not held), up to $280{ }^{\circ} \mathrm{C}$ at $5{ }^{\circ} \mathrm{C} / \mathrm{min}$ (not held), up to $300^{\circ} \mathrm{C}$ at $10^{\circ} \mathrm{C} / \mathrm{min}$ (held for $12 \mathrm{~min}$ ). The injector temperature was $280{ }^{\circ} \mathrm{C}$ and the total GC running time was 40-50 $\mathrm{min}$ [48]. The mass spectrometer was operated in the positive electron ionization (EI) mode with an ionization energy of $70 \mathrm{eV}$. The solvent delay was 0-3.0 min. A scan interval of 0.5 seconds was used and fragments from $\mathrm{m} / \mathrm{z}$ of 50 to $500 \mathrm{Da}$ were programmed. The inlet temperature was set at $290{ }^{\circ} \mathrm{C}$, while the source temperature was $250{ }^{\circ} \mathrm{C}$. The relative percentage amount of each component was calculated by comparing its average peak area to the total areas. The software adapted to handle mass spectra and chromatograms was MS Workstation 8. The NIST Version 11.0 library database of National Institute Standard and Technology (NIST), containing more than 62,000 patterns, was used for identifying the chemical components. The spectra of the unknown components were compared with the spectra of known components stored in the NIST library.

\subsection{Statistical Analysis}

The data are given as means \pm SD. The results were compared by one-way analysis of variance (ANOVA). Tukey's test was used to identify significant differences among the means. Differences at the $5 \%$ level $(p<0.05)$ were considered statistically significant.

\section{Conclusions}

Bronchial asthma is a serious public health problem, affecting people of all ages with characterized symptoms. Exposure to fungal agents can worsen asthmatic symptoms. Antifungal therapeutic failures augmented the cost of treatment, morbidity, and mortality of most asthmatic cases. The present study shows that the selected marine macroalgae have excellent fungicidal activity against various fungal pathogens, which can assist recovery in chronic asthmatic states. In particular, the antifungal activity of L. paniculata was found to be excellent, and it can be recommended as a promising candidate for further fractionation to obtain novel antifungal substances. Future research investigating the synergistic effects of novel antifungal substances on major asthma mechanisms in vivo in an animal model of asthma is underway.

Author Contributions: S.M. designed and carried out the research work, and wrote the manuscript. W.A. was actively involved immunological assays with S.M., and made the critical revisions of the manuscript. The authors approved the final draft and are accountable for its accuracy and integrity.

Funding: We gratefully acknowledge the Basic Science Research Unit, Deanship of Scientific Research, Majmaah University, Kingdom of Saudi Arabia (Project No: 49/37, signed dated: 26/03/1438) for research funding assistance. 
Acknowledgments: We thankfully acknowledge the faculty members of Central Bioscience Research Laboratories (CBRL) College of Science, Al Zulfi, the asthmatic patients, the medical consultants Sajad Ahamed Mir MD. MRCP (UK) and Adnan MBBS., Nursing staff, Abdulaziz Jassir Alshalani, Head, Laboratory and Blood Bank, and the Administrative Head of Zulfi General Hospital, Al Zulfi city, Kingdom of Saudi Arabia.

Conflicts of Interest: The authors declare no conflicts of interest.

\section{Abbreviations}

$\begin{array}{ll}\mu g & \text { Microgram } \\ \text { AMR } & \text { Antimicrobial resistance } \\ \text { CLSI } & \text { Clinical and Laboratory Standards Institute } \\ \text { ELISA } & \text { Enzyme-linked immunosorbent assay } \\ \text { GC-MS/MS } & \text { Gas chromatography/tandem mass spectrometry } \\ \text { ICS } & \text { Inhaled corticosteroids } \\ \text { IgE } & \text { Immunoglobulin E } \\ \text { IU } & \text { International unit } \\ \text { MIC } & \text { Minimum inhibitory concentration } \\ \text { MFC } & \text { Minimum fungicidal concentration } \\ \text { mL } & \text { Milliliter } \\ \text { MW } & \text { Molecular weight } \\ \text { NIST } & \text { National Institute Standard and Technology } \\ \text { RPMI } & \text { Roswell Park Memorial Institute } \\ \text { RT } & \text { Retention time } \\ \text { SABA } & \text { Short-acting beta-agonist } \\ \text { UK } & \text { United Kingdom } \\ \text { USA } & \text { United States of America }\end{array}$

\section{References}

1. Morgan, B.W.; Grigsby, M.R.; Siddharthan, T.; Chowdhury, M.; Rubinstein, A.; Gutierrez, L.; Irazola, V.; Miranda, J.J.; Bernabe-Ortiz, A.; Alam, D.; et al. Epidemiology and Risk Factors of Asthma-COPD Overlap in Low- and Middle-Income Countries. J. Allergy Clin. Immunol. 2018. [CrossRef] [PubMed]

2. Bleecker, E.R.; Panettieri, R.A., Jr.; Wenzel, S.E. Clinical Issues in Severe Asthma: Consensus and Controversies on the Road to Precision Medicine. Chest 2018, 154, 982-983. [CrossRef] [PubMed]

3. Suresh, M.; Rath, P.K.; Panneerselvam, A.; Dhanasekaran, D.; Thajuddin, N. Antifungal activity of selected Indian Medicinal Plant salts. J. Glob. Pharma Technol. 2010, 2, 71-74.

4. Hayes Watson, C.; Nuss, H.; Celestin, M.; Tseng, T.S.; Parada, N.; Yu, Q.; Moody-Thomas, S. Health beliefs associated with poor disease self-management in smokers with asthma and/or COPD: A pilot study. J. Asthma 2018, 1-8. [CrossRef] [PubMed]

5. O'Neill, J. Antimicrobial resistance: Tackling a crisis for the health and wealth of nations. Rev. Antimicrob. Resist. 2014, 11, 1-6.

6. Roemer, T.; Krysan, D.J. Antifungal drug development: Challenges, unmet clinical needs, and new approaches. Cold Spring Harb. Perspect. Med. 2014, 4, a019703. [CrossRef] [PubMed]

7. Alsaid-Habia, T.; McLeish, A.C.; Kraemer, K.M. Associations between distress tolerance and asthma symptoms and quality of life. J. Asthma 2018, 4, 1-8. [CrossRef] [PubMed]

8. Mickymaray, S.; Al Aboody, M.S.; Rath, P.K.; Annamalai, P.; Nooruddin, T. Screening and antibacterial efficacy of selected Indian medicinal plants. Asian Pac. J. Trop. Biomed. 2016, 6, 185-191. [CrossRef]

9. Shannon, E.; Abu-Ghannam, N. Antibacterial derivatives of marine algae: An overview of pharmacological mechanisms and applications. Mar. Drugs 2016, 14, 81. [CrossRef] [PubMed]

10. Gheda, S.F.; El-Adawi, H.I.; EL-Deeb, N.M. Antiviral Profile of Brown and Red Seaweed Polysaccharides against Hepatitis C Virus. Iran. J. Pharm. Res. 2016, 15, 483-491. [PubMed] 
11. De Alencar, D.B.; de Carvalho, F.C.; Rebouças, R.H.; dos Santos, D.R.; dos Santos Pires-Cavalcante, K.M.; de Lima, R.L.; Baracho, B.M.; Bezerra, R.M.; Viana, F.A.; dos Fernandes Vieira, R.H.; et al. Bioactive extracts of red seaweeds Pterocladiella capillacea and Osmundaria obtusiloba (Floridophyceae: Rhodophyta) with antioxidant and bacterial agglutination potential. Asian Pac. J. Trop. Med. 2016, 9, 372-379. [CrossRef] [PubMed]

12. Gutiérrez-Rodríguez, A.G.; Juárez-Portilla, C.; Olivares-Bañuelos, T.; Zepeda, R.C. Anticancer activity of seaweeds. Drug Discov. Today 2017, 23, 434-447. [CrossRef] [PubMed]

13. Roberton, R.C.; Guihéneuf, F.; Bahar, B.; Schmid, M.; Stengel, D.B.; Fitzgerald, G.F.; Paul Ross, R.; Stanton, C. The Anti-Inflammatory effect of algae-derived lipid extracts on lipopolysaccharide (LPS)-stimulated human THP-1 macrophages. Mar. Drugs 2015, 13, 5402-5424. [CrossRef] [PubMed]

14. Cabrita, M.; Vale, C.; Rauter, A. Halogenated compounds from marine algae. Mar. Drugs 2010, 8, $2301-2317$. [CrossRef] [PubMed]

15. Michalak, I.; Chojnacka, K. Algae as production systems of bioactive compounds. Eng. Life Sci. 2015, 15, 160-176. [CrossRef]

16. Bouhlal, R.; Riadi, H.; Martínez, J.; Bourgougnon, N. The antibacterial potential of the seaweeds (Rhodophyceae) of the Strait of Gibraltar and the Mediterranean coast of Morocco. Afr. J. Biotechnol. 2010, 9, 6365-6372.

17. Pierre, G.; Sopena, V.; Juin, C.; Mastouri, A.; Graber, M.; Maugard, T. Antibacterial activity of a sulfated galactan extracted from the marine alga Chaetomorpha aerea against Staphylococcus aureus. Biotechnol. Bioprocess Eng. 2011, 16, 937-945. [CrossRef]

18. Al-Saif, S.S.A.; Abdel-Raouf, N.; El-Wazanani, H.A.; Aref, I.A. Antibacterial substances from marine algae isolated from Jeddah coast of Red sea, Saudi Arabia. Saudi J. Biol. Sci. 2014, 21, 57-64. [CrossRef] [PubMed]

19. Kavita, K.; Singh, V.K.; Jha, B. 24-Branched delta 5 sterols from Laurencia papillosa red seaweed with antibacterial activity against human pathogenic bacteria. Microbiol. Res. 2014, 169, 301-306. [CrossRef] [PubMed]

20. Osman, M.E.; Abushady, A.M.; Elshobary, M.E. In vitro screening of antimicrobial activity of extracts of some macroalgae collected from Abu-Qir bay Alexandria, Egypt. Afr. J. Biotechnol. 2010, 9, 7203-7208.

21. Adaikalaraj, G.; Patric, R.D.; Johnson, M.; Janakiraman, N.; Babu, A. Antibacterial potential of selected red seaweeds from Manapad coastal areas, Thoothukudi, Tamil Nadu, India. Asian Pac. J. Trop. Biomed. 2012, 2 , S1077-S1080. [CrossRef]

22. Jassbi, A.R.; Mohabati, M.; Eslami, S.; Sohrabipour, J.; Miri, R. Biological activity and chemical constituents of red and brown algae from the Persian Gulf. Iran. J. Pharm. Res. 2013, 12, 339-348. [PubMed]

23. De Jesus Raposo, M.F.; de Morais, A.M.B.; de Morais, R.M.S.C. Marine polysaccharides from algae with potential biomedical applications. Mar. Drugs 2015, 13, 2967-3028. [CrossRef] [PubMed]

24. Krish, S.; Das, A. In-vitro bioactivity of marine seaweed, Cladophora rupestris. Int. J. Pharm. Biol. Sci. 2014, 5, 898-908.

25. Karthikeyan, K.; Shweta, K.; Jayanthi, G.; Prabhu, K.; Thirumaran, G. Antimicrobial and antioxidant potential of selected seaweeds from Kodinar, Southern Coast of Saurashtra, Gujarat, India. J. Appl. Pharm. Sci. 2015, 5, 35-40. [CrossRef]

26. Rahelivao, M.P.; Gruner, M.; Andriamanantoanina, H.; Andriamihaja, B.; Bauer, I.; Knölker, H.J. Red algae (Rhodophyta) from the coast of Madagascar: Preliminary bioactivity studies and isolation of natural products. Mar. Drugs 2015, 13, 4197-4216. [CrossRef] [PubMed]

27. Alarif, W.M.; Al-Lihaibi, S.S.; Abdel-Lateff, A.; Ayyad, S.E. New antifungal cholestane and aldehyde derivatives from the red alga Laurencia papillosa. Nat. Prod. Commun. 2011, 6, 1821-1824. [PubMed]

28. Chowdhury, M.M.H.; Kubra, K.; Hossain, M.B.; Mustafa, M.G.; Jainab, T.; Karim, M.R.; Mehedy, M.E. Screening of Antibacterial and Antifungal Activity of Freshwater and Marine Algae as a Prominent Natural Antibiotic Available in Bangladesh. Int. J. Pharmacol. 2015, 11, 828-833. [CrossRef]

29. Shobier, A.H.; Ghani, S.A.A.; Barakat, K.M. GC/MS spectroscopic approach and antifungal potential of bioactive extracts produced by marine macroalgae. Egypt J. Aquat. Res. 2016, 42, 289-299. [CrossRef]

30. Mashjoor, S.; Yousefzadi, M.; Esmaeili, M.A.; Rafiee, R. Cytotoxicity and antimicrobial activity of marine macro algae (Dictyotaceae and Ulvaceae) from the Persian Gulf. Cytotechnology 2016, 68, 1717-1726. [CrossRef] [PubMed] 
31. Ertürk, Ö.; Taş, B. Antibacterial and antifungal effects of some marine algae. Kafkas Univ. Vet. Fak. Derg. 2011, 17, S121-S124.

32. Guedes, E.A.; Araújo, M.A.; Souza, A.K.; de Souza, L.I.; de Barros, L.D.; Maranhão, F.C.; Sant'Ana, A.E. Antifungal activities of different extracts of marine macroalgae against dermatophytes and Candida species. Mycopathologia 2012, 174, 223-232. [CrossRef] [PubMed]

33. Pandian, P.; Selvamuthukumar, S.; Manavalan, R.; Parthasarathy, V. Screening of antibacterial and antifungal activities of red marine algae Acanthaphora specifera (Rhodophyceae). J. Biomed. Sci. Res. 2011, 3, 444-448.

34. Genovese, G.; Leitner, S.; Minicante, S.A.; Lass-Flörl, C. The Mediterranean red alga Asparagopsis taxiformis has antifungal activity against Aspergillus species. Mycoses 2013, 56, 516-519. [CrossRef] [PubMed]

35. Suresh, M.; Rath, P.K.; Panneerselvam, A.; Dhanasekaran, D.; Thajuddin, N. Anti-mycobacterial effect of leaf extract of Centella asiatica. Res. J. Pharm Technol. 2010, 3, 872-876.

36. Sun, J.; Shi, D.; Ma, M.; Li, S.; Wang, S.; Han, L.; Yang, Y.; Fan, X.; Shi, J.; He, L. Sesquiterpenes from the red alga Laurencia tristicha. J. Nat. Prod. 2005, 68, 915-919. [CrossRef] [PubMed]

37. Ji, N.Y.; Li, X.M.; Ding, L.P.; Wang, B.G. Diterpenes, sesquiterpenes, and a C15-acetogenin from the marine red alga Laurencia mariannensis. J. Nat. Prod. 2007, 70, 1901-1905. [CrossRef] [PubMed]

38. Ji, N.Y.; Li, X.M.; Ding, L.P.; Wang, B.G. Aristolane sesquiterpenes and highly brominated indoles from the marine red alga Laurencia similis (Rhodomelaceae) Helv. Chim. Acta 2007, 90, 385-391. [CrossRef]

39. Ji, N.Y.; Li, X.M.; Li, K.; Wang, B.G. Halogenated sesquiterpenes from the marine red alga Laurencia saitoi (Rhodomelaceae) Helv. Chim. Acta 2009, 92, 1873-1879. [CrossRef]

40. Liang, Y.; Li, X.M.; Cui, C.M.; Li, C.S.; Wang, B.G. A new rearranged chamigrane sesquiterpene from Laurencia okamurai. Chin. Chem. Lett. 2009, 20, 190-192. [CrossRef]

41. Liang, Y.; Li, X.M.; Cui, C.M.; Li, C.S.; Sun, H.; Wang, B.G. Sesquiterpene and acetogenin derivatives from the marine red alga Laurencia okamurai. Mar. Drugs 2012, 10, 2817-2825. [CrossRef] [PubMed]

42. Abbassy, M.A.; Marzouk, M.A.; Rabea, E.I.; Abd-Elnabi, A.D. Insecticidal and fungicidal activity of Ulva lactuca Linnaeus (Chlorophyta) extracts and their fractions. Annu. Res. Rev. Biol. 2014, 4, 2252-2262. [CrossRef]

43. Magaldi, S.; Mata-Essayag, S.; Hartung de Capriles, C.; Colellaa, M.T.; Olaizolaa, C.; Ontiverosb, Y. Well diffusion for antifungal susceptibility testing. Int. J. Infect. Dis. 2004, 8, 39-45. [CrossRef] [PubMed]

44. CLSI. Method for Antifungal Disk Diffusion Susceptibility Testing of Nondermatophyte Filamentous Fungi; Approved Guideline; CLSI Document M51-A; Clinical and Laboratory Standards Institute: Wayne, PA, USA, 2010.

45. CLSI. Reference Method for Broth Dilution Antifungal Susceptibility Testing of Filamentous Fungi; Approved Standard; CLSI Document M38-A; Clinical and Laboratory Standards Institute: Wayne, PA, USA, 2002.

46. Borman, A.M.; Fraser, M.; Palmer, M.D.; Szekely, A.; Houldsworth, M.; Patterson, Z.; Johnson, E.M. MIC Distributions and Evaluation of Fungicidal Activity for Amphotericin B, Itraconazole, Voriconazole, Posaconazole and Caspofungin and 20 Species of Pathogenic Filamentous Fungi Determined Using the CLSI Broth Microdilution Method. J. Fungi 2017, 3, E27. [CrossRef] [PubMed]

47. Vijayakumar, R.; Sandle, T.; Al-Aboody, M.S.; AlFonaisan, M.K.; Alturaiki, W.; Mickymaray, S.; Premanathan, M.; Alsagaby, S.A. Distribution of biocide resistant genes and biocides susceptibility in multidrug-resistant Klebsiella pneumoniae, Pseudomonas aeruginosa and Acinetobacter baumannii-A first report from the Kingdom of Saudi Arabia. J. Infect. Public Health 2018, 11, 812-816. [CrossRef] [PubMed]

48. Srinivasan, K.; Kumaravel, S. Unraveling the potential phytochemical compounds of Gymnema sylvestre through GC-MS study. Int. J. Pharm. Pharm. Sci. 2016, 8, 1-4.

Sample Availability: Not available. 